\title{
TERMIN ,TRANSIDIOMATYCZNOŚĆ" JAKO PRÓBA ZNALEZIENIA ADEKWATNEGO LINGWISTYCZNEGO UJĘCIA DLA NIEKTÓRYCH WĄTKÓW GLOTTODYDAKTYCZNYCH
}

\begin{abstract}
Słowa kluczowe: homonimia międzyjęzykowa, interkomprehensja, glottodydaktyka, języki słowiańskie

Streszczenie. Treścią artykułu jest propozycja terminologiczna mająca na celu uzupełnienie systemu pojęć charakteryzujących interakcję systemów językowych w różnych sytuacjach komunikowania się ich użytkowników, w tym w sytuacji przyswajania jednego z tych systemów (glottodydaktyka). Proponowany przez autora termin „transidiomatyczność” ma oznaczać właściwość elementu systemu językowego, która potencjalnie objawia się w komunikacji jako niekontrolowane przełączenie kodu językowego na skutek podobieństwa tego elementu do analogicznego elementu innego systemu językowego. „Transidiomatyczność” jest pojęciem nadrzędnym w stosunku do takiego pojęcia jak np. ,homonimia międzyjęzykowa”, ponieważ po pierwsze zakłada nie tylko przełączenie kodu zakłócające komunikację (interferencja językowa), lecz także możliwość skutecznego wspierania komunikacji środkami zaczerpniętymi z innego systemu (pozytywny transfer językowy, interkomprehensja), a po drugie może być stosowane nie tylko do jednostek systemu leksykalnego, lecz do każdego innego poziomu systemu językowego (przy zastosowaniu odpowiedniego uściślenia nominacyjnego).
\end{abstract}

Pojęcie tytułowe tego artykułu pojawiło się w trakcie rozważań nad zjawiskiem określanym często jako „homonimia międzyjęzykowa”. Używa się na jego oznaczenie także innych nazw, ogółem może nawet kilkunastu, wśród których najbardziej znana jest chyba „,fałszywi przyjaciele [tłumacza]” («faux-amis») (Tezaurus..., 1998, s. 85).

Badania określanych w ten sposób zjawisk zrobiły się ostatnio dość popularne (Kaleta 2014; Kusal' 2006; Pančiková 2005), odbyły się nawet dwie międzynarodowe konferencje organizowane przez UKSW. W tomie, który ukazał się po

*babanov@spbu.ru, Uniwersytet Państwowy w Sankt Petersburgu, Wydział Filologiczny, Katedra Filologii Słowiańskiej, ul. Universitetskaya Naberezhnaya 11, 199034 Sankt Petersburg, Rosja. 
pierwszej z tych konferencji, jest obszerna bibliografia zagadnienia (zob. Majewska 2017a) oraz bardzo cenny artykuł Małgorzaty Majewskiej, poświęcony prawie w całości sprawom terminologicznym (Majewska 2017b). Autorka przytacza przekonujące dowody zgodności terminu „homonimia międzyjęzykowa” z teorią lingwistyczną zarówno $\mathrm{w}$ czasach jego pierwszego pojawienia się (na przełomie lat 50. i 60. XX wieku), jak też w dniu dzisiejszym, pokazuje jego poręczność jako podstawy do nazywania różnych przypadków szczegółowych występowania omawianego zjawiska, ale podaje też przyczyny powodujące, że dyskusje terminologiczne na pewno pozostaną na porządku dziennym. Wynika to z różnic stosowania pojęcia „homonimia” w tradycjach lingwistycznych różnych języków, z wielości już istniejących nazw dla badanego zjawiska, z różnicy dziedzin praktycznych, w których mają z nim do czynienia przede wszystkim zwykli uczestnicy komunikacji międzyjęzykowej.

Nawet jeżeli dojdzie do powszechnej akceptacji terminu „homonimia międzyjęzykowa", pozostanie problem zakwalifikowania do niego tych czy innych zjawisk. Mając do czynienia z różnymi systemami (językami), zazwyczaj musimy dokonywać pewnych uproszczeń, postulując zbieżność strony formalnej zestawianych jednostek czy też różnice semantyczne pomiędzy nimi. Ale jak daleko posunięta może być dopuszczalność tych uproszczeń? Z punktu widzenia teorii lingwistycznej jest to sprawa bardzo istotna, ponieważ na przykład w wielu przytaczanych parach rosyjsko-polskich homonimów międzyjęzykowych można stwierdzić poważne różnice fonetyczne wynikające bądź ze specyfiki wymowy niektórych głosek w zestawianych językach, bądź z różnego rozwoju wspólnego dziedzictwa fonetycznego. W Rosyjsko-polskim słowniku homonimów międzyjęzykowych K. Kusala jako homonimy międzyjęzykowe są podane zarówno korela-

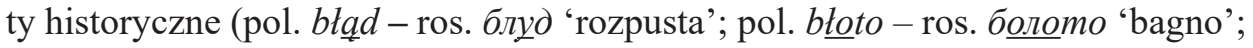
pol. kłódka - ros. колодка 'oprawa drewniana'; 'szczęka, klocek'; 'baretka'; 'kopyto'; 'dyby' (Kusal' 2002), jak i wyrazy różniące się wymową głosek, a nawet ich statusem fonematycznym (pol. krawat - ros. кровать 'łóżko'; pol. $\underline{d y w a n}$ - ros. $\underline{\partial u в а н ~ ' k a n a p a ~(K u s a l ' ~ 2002) . ~ W y r a z y ~ t e ~ j e d n a k ~ w ~ s y t u a c j i ~ n a u k i ~ j e ̨ z y k a ~ l u b ~}$ komunikacji opartej na interkomprehensji (o tym pojęciu nieco szerzej w dalszym ciągu niniejszego artykułu) bywają mylnie kojarzone ze sobą. A skoro badania homonimii międzyjęzykowej mają źródła praktyczne, uwzględnienie w słowni$\mathrm{ku}$ „homonimów międzyjęzykowych” takich, ostrożnie mówiąc, nieidealnych z punktu widzenia fonetyki par, nie wywołuje sprzeciwu.

W przypadku semantyki sytuacja może być odwrotna: wyrazy mogą oznaczać w zasadzie ten sam denotat, ale różnie go wartościować. Na przykład pol. woń i ros. вонь 'smród' oznaczają zjawiska zbliżone (czynnik odbierany za pomocą zmysłu powonienia), dlatego w jednym z rosyjskich słowników synonimów zarówno вонь, jak i заnаx 'woń' znajdujemy pod tym samym hasłem jako możliwe synonimy do зловоние 'smród' (Aleksandrova 2010, s. 150) - wprawdzie 
3anax 'woń' występuje w tym samym słowniku jako możliwy synonim do apoмam 'zapach' (Aleksandrova 2010, s. 19). Z tego wynika, że jest wyrazem nienacechwanym, niewartościującym, że odcieni wartościujących może nabierać w kontekście. Użycie (pod wpływem języka polskiego) w komuniukacji w języku rosyjskim zamiast słowa заnах słowa вонь nie wpłynie na rozumienie opisywanej sytuacji, ale spowoduje mylne zrozumienie tego, jak opisywana sytuacja jest oceniana przez rozmówcę, co też należy uznać za zakłócenie komunikacji. Ze względów praktycznych więc znów warto dopuścić się odstępstwa od ścisłości lingwistycznej i zaliczyć do przejawów homonimii międzyjęzykowej pary, w których różnica semantyczna nie dotyczy podstawowego znaczenia wyrazów.

Jeszcze większe wątpliwości budzi zastosowanie tego określenia w szerszym kontekście, w odniesieniu do innych obszarów systemu językowego, np. do frazeologii. Właściwie okazuje się, że międzyjęzykowymi homonimami frazeologicznymi nazywane są połączenia wyrazowe, które mogą okazać się mylnie zinterpretowane przez kogoś, kto nie zna frazeologii odpowiedniego języka, lub niepoprawnie utworzone pod wpływem frazeologii innego (lepiej znanego) języka. Dlatego wśród przykładów obok zwrotów jako tako pasujących do pojęcia „homonimii międzyjęzykowej” (ros. ходить по головам 'zmierzać do swojego prywatnego celu bezwzględnie, nachalnie' - czes. chodit po hlavě 'swawolić, wygłupiać się') pojawiają się także takie, które po prostu w jednym z języków nie są zwrotami frazeologicznymi (ros. на свою голову (делать что) ironiczne 'robić coś powodując negatywne konsekwencje dla siebie' - czes. na svou hlavu 'na swoją głowę', nie ma znaczenia innego niż dosłowne; czes. nevleze $v$ botách do vody 'nie pozwoli siebie oszukać' - ros. не полезет в ботинках в воду 'nie będzie wchodzić w butach do wody', nie ma znaczenia innego niż dosłowne), a nawet takie, które w obu językach są idiomami, ale różnią się jednym ze składników (ros. сердие у него упало в пятки 'przestraszył się', dosłownie: 'serce mu spadło do pięt' - czes. srdce mu spadlo do bot - to samo, dosłownie: 'serce mu spadło do butów' $)^{1}$.

W powyższych przykładach odejścia od ścisłego rozumienia homonimii uzasadnieniem okazuje się praktyczna przydatność rozwiązania, a dominacja tego kryterium wynika z faktu, że właśnie praktyka okazuje się punktem wyjściowym badania: praktycy zauważają jakieś zakłócenie w komunikacji, spowodowane pozornym podobieństwem jednostek lub struktur w dwu różnych językach, a w refleksji nad tym zakłóceniem sięgają do pojęcia z lingwistyki opisowej, które wydaje się najstosowniejsze dla wyjaśnienia przyczyn nieporozumienia. Nie ma w tym nic złego, bo jest to jedna z normalnych ścieżek rozwoju i gromadzenia wiedzy. Jednakże po pewnym okresie takiego gromadzenia empirycznego materiału przychodzi czas na podsumowanie rozmaitych faktów, mających wspólne podłoże i ujęcie ich w ogólnej koncepcji o potencjale prognostycznym, wskazując

${ }^{1}$ Wszystkie przytoczone przykłady pochodzą z artykułu Ignatyevej (2016) 
ewentualne obszary badań obiecujących nowe praktyczne rozwiązania. Wypracowanie takiej koncepcji może wymagać m.in. odejścia od aktualnie używanych pojęć terminologicznych lub ich należytego umiejscowienia w ramach ogólniejszej koncepcji.

Spróbujmy zatem zastanowić się nad istotą nieporozumień w sytuacji występowania w komunikacji tzw. „homonimów międzyjęzykowych” i być może umieścić to zjawisko w nieco szerszym kontekście. Chyba nie będzie wielkim błędem twierdzenie, że mamy tu do czynienia z sytuacją, kiedy strona formalna znaku ewokuje w świadomości odbiorcy stronę semantyczną należącą do innego systemu znakowego, a dzieje się tak dlatego, że strona oznaczająca odpowiednia do tej semantyki jest $\mathrm{w}$ jakiś sposób kojarzona $\mathrm{z}$ bodźcem pochodzącym $\mathrm{z}$ innego systemu. Mechanizm kojarzenia może być różny: podobieństwo dźwiękowe niepoparte podobieństwem graficznym ani zestawieniami historycznymi (pol. wróżka [vruška] - ros. врушка [vruška] 'kłamczucha'), podobieństwo graficzne niepoparte podobieństwem fonetycznym (pol. baby (D. 1.p. lub M./B. 1.mn. rzeczownika $b a b a)$ - ang. baby 'dziecko'), podobieństwo tworzących leksem mniejszych jednostek znaczących (pol. nocnik - ros. ночник 'lampa nocna' - w obu przypadkach derywat został utworzony od tej samej bazy słowotwórczej noc-/ноч- za pomocą tego samego formantu -nik/-нuк), znajomość regularnych oboczności występujących przy zestawieniu morfemów konkretnej pary języków (pol. dworzec - ros. двореи 'pałac, zamek') itp. Zależnie od tego, w czym występuje podobieństwo, homonimy międzyjęzykowe można odpowiednio poklasyfikować, ale nie jest to celem niniejszej refleksji. Ważniejszy wydaje się tu być fakt, że niezależnie od bezpośredniej przyczyny kojarzenia form językowych dwu języków w świadomości osoby dwujęzycznej następuje niekontrolowane przełączenie kodu językowego. Dwujęzyczna osoba, w której świadomości dochodzi do przełączenia kodu, nie zdaje sobie z tego sprawy (przynajmniej w samym momencie przełączenia), właśnie dlatego, że jest dwujęzyczna, a język, na który niezauważalnie dla siebie samej ,przeskoczyła”, jest dla niej bardziej zrozumiały i wygodny, niż ten, z którego „się przełączyła” (niekoniecznie bardziej zrozumiały i wygodny w ogóle i pod każdym względem, ale na pewno w zakresie tej tematyki, która stanowiła przedmiot komunikacji).

Trzeba zauważyć też, że nie zawsze takie przełączenie kodu powoduje zakłócenia komunikacyjne. Wręcz przeciwnie, ,zrozumienie” lub nawet aktywne użycie jednostki wydedukowanej na wzór jednostki z innego języka może się okazać zupełnie poprawne, a sam fakt przełączenia kodu, skoro był on niekontrolowany, spontaniczny, podświadomy, zostaje niezauważony. Szczególnie często dochodzi do takich przełączeń w przypadku współistnienia (w świadomości komunikantów lub w przestrzeni komunikacyjnej) języków o wielkim stopniu podobieństwa wynikającego bądź ze wspólnej genezy, bądź z długotrwałego kontaktu. Na oznaczanie komunikacji z wykorzystywaniem podobieństw mię- 
dzy językami komunikantów został ukuty nawet specjalny termin ,interkomprehensja". Terminu tego najczęściej używają glottodydaktycy mający do czynienia z językami romańskimi (Gębal 2016; Hemming i in. 2011; Jamet 2009) - być może dlatego, że podobieństwa pomiędzy językami romańskimi często okazują się wystarczające dla takiej komunikacji. Samo zjawisko jednak występuje (oczywiście w różnej skali) w relacjach pomiędzy komunikantami używającymi także różnych innych języków, niekoniecznie o wysokim stopniu bliskości genetycznej lub kontaktowej. Zjawisko to zostało uwzględnione i pozytywnie ocenione nawet w dokumentach gremiów doradzających władzom Unii Europejskiej w sprawach polityki językowej².

Mamy zatem w dorobku myśli lingwistycznej dwa pojęcia związane z sytuacją przełączenia kodu językowego w komunikacji między osobami należącymi prymarnie do różnych społeczności językowych. Jedno z nich oznacza zjawisko dotyczące systemu językowego i potencjalnie powodujące zakłócenia komunikacji (homonimia międzyjęzykowa), drugie dotyczy funkcjonowania systemu i oznacza raczej udaną komunikację, którą wspomogło przełączenie kodu (interkomprehensja). Istnieją także inne pojęcia związane ze współdziałaniem różnych kodów językowych w komunikacji: interferencja i transfer językowy. Interferencja oznacza zakłócenia komunikacyjne spowodowane wpływem systemu językowego innego niż ten, w którym się odbywa komunikacja (omawiana wyżej homonimia międzyjęzykowa może być przyczyną interferencji). Można ją określić także jako skutek nieudanej próby zastosowania w komunikacji możliwości interkomprehensji. Transfer językowy jest pojęciem nadrzędnym, oznaczającym posługiwanie się jednostkami lub strukturami jednego języka przy komunikowaniu w innym języku. Skutki transferu mogą być zarówno pozytywne (interkomprehensja), jak i negatywne (interferencja). Ponieważ termin ,interkomprehensja” w dydaktyce języków słowiańskich jest stosunkowo nowy, tradycyjnie terminu „transfer językowy” używało się jako pozytywnego odpowiednika interferencji (Szapkina 1997).

Wydaje się, że wśród wypracowanych dotychczas pojęć, opisujących proces lub skutek przełączenia kodu językowego w trakcie komunikacji oraz elementy systemu językowego, które mogą prowokować takie przełączenie, brakuje pojęcia nadrzędnego, charakteryzującego elementy systemu językowego pod kątem ich zdolności przekraczania granicy językowej. Brakuje także pojęcia na oznaczanie elementów systemowych ułatwiających komunikowanie się z nosicielami innego języka lub przyswajanie tego języka, ale, jak pokazuje przykład terminu ,transfer", w przypadku istnienia pojęcia nadrzędnego ten mniejszy brak nie jest trudny do nadrobienia. Na oznaczenie znaku językowego lub innego elementu systemu językowego, który może prowokować przełączenie kodu, proponuję przyjęcie terminu tran si di o mat y z m, natomiast na oznaczenie tej cechy znaku języko-

\footnotetext{
${ }^{2}$ http://www.kongrespolonistow2016.us.edu.pl/panel_8.php) [08.06.2020].
} 
wego - terminu tra n s i d i o m a t y c z n o ść. Znaczenie składników tego terminu sugeruje zdolność elementu systemu językowego do przekraczania granic tego systemu, w którym go znajdujemy. Oczywiście zdolność ta jest relatywna - występuje względem jakiegoś konkretnego innego języka. Jest to ograniczenie ważne nawet w przypadku języków blisko spokrewnionych, np. polski wyraz hańba jest transidiomatyczny względem języka czeskiego lub ukraińskiego, a nie jest transidiomatyczny względem języka rosyjskiego.

Zależnie od wpływu na skuteczność komunikacji możemy rozróżniać transidiomatyczność wspierającą (sprzyjającą) lub hamującą (zakłócającą).

Transidiomatyczność może występować na wszystkich poziomach systemu językowego. Przykłady klasycznych homonimów międzyjęzykowych możemy zaliczyć do transidiomatyzmów zakłócających leksykalnych, do transidiomatyzmów leksykalnych wspierających należy przytoczony wyżej przykład hańba (transidiomatyzm polsko-ukraiński lub polsko-czeski). Ponieważ przeważnie materiałem do tego artykułu są zjawiska z pogranicza polsko-rosyjskiego, przypomnijmy kilka transidiomatyzmów leksykajnych wspierających, występujących na tym obszarze. Ze względu na różnicę alfabetów, wspierających transidiomatyzmów mających także podobieństwo graficzne tu raczej nie możemy się spodziewać. Poniekąd można w ten sposób scharakteryzować parę ros. мaмa-pol. mama, ale pod warunkiem, że zapiszemy obydwa słowa dużymi literami (MAMA). Częstym zjawiskiem są natomiast transidiomatyzmy oparte tylko na podobieństwie brzmienia (dla bardziej wyrazistego zademonstrowania zjawiska przytoczmy je w nieco uproszczonej transkrypcji fonetycznej): [dom] (dom/дoм), [kam'en'] (kamień/камень), [p'ivo] (piwo/пиво), [stal'] (stal/cmaль), [bagažnik] (bagażnik /багажник) itp. Lista wyrazów, które mogą być uznane za wspierające transidiomatyzmy leksykalne poszerzy się kilkakrotnie, jeżeli uwzględnimy regularne różnice fonetyczne pomiędzy językiem rosyjskim a polskim, poczynając od miejsca akcentu (bagaż/багаж; bilet/билет; woda/вода; baran/баран itp.), a kończąc na bardziej skomplikowanych obocznościach będących wynikiem różnic w rozwoju dziedzictwa fonetycznego prasłowiańszczyzny (las/леc, siano/сено, gniazdo /гнездо, kolano/колено itp.; dąb/дуб, ząb/зуб itp.; droga/дорога, wrona/ворона, krowa/корова itp; rzeka/река, rzера/pena, grzech/гpex, krzyk/крик, grzyb/гриб itp.; brzeg/берег, drzewo/дерево itp.).

Dla zademonstrowania potencjału pojęcia transidiomatyczności zwróćmy uwagę na przykłady tego zjawiska $\mathrm{z}$ innych poziomów systemu językowego, wśród których da się znaleźć zarówno transidiomatyzmy wspierające, jak i zakłócające. Będą to tylko transidiomatyzmy polskie względem języka rosyjskiego, ale pamiętajmy, że analogicznych zjawisk można się doszukiwać w każdej innej parze języków. Można też sytuację odwrócić i szukać rosyjskich transidiomatyzmów względem języka polskiego. Przypuszczam, że nie zawsze to będzie tylko odwrócenie przykładów polsko-rosyjskich. 
Za przykład transidiomatyczności fonetycznej wspierającej mogą posłużyć spółgłoski szczelinowe [š], [̌̌]. Rosjanie nie mają żadnych problemów z ich rozpoznawaniem i wymawianiem, chyba że mają problem $z$ tymi głoskami w swoim ojczystym języku, ale to już nie jest problem glottodydaktyczny, lecz logopedyczny.

Natomiast polskie głoski [ś] i [ź] należy potraktować jako transidiomatyzm fonetyczny zakłócający. Jeżeli Rosjanin nie uczył się specjalnie języka polskiego, a zwłaszcza nie miał polskiego drylu fonetycznego, jest wielce prawdopodobne, że będzie mylnie kojarzyć polskie głoski [ś] i [ź] z rosyjskimi głoskami [šs, [ž]. Przykładowo imię osobowe Kasia odebrane ze słuchu może kojarzyć się Rosjaninowi z kasza.

O transidiomatyczności morfemowej możemy mówić w przypadku wielu afiksów słowotwórczych. Przykładowo Rosjanom nie sprawia trudności interpretacja semantyczna przyrostków -acz, -ak, -nik, gdyż analogiczne przyrostki o podobnych funkcjach semantycznych występują także w języku rosyjskim. Czyli mamy tu do czynienia z transidiomatycznością wspierającą komunikację. Natomiast o ile nie wprowadzi się uprzedzającej informacji, przyrostek -czyk zostaje mylnie zinterpretowany jako deminutywny, ponieważ taką semantykę ma rosyjski przyrostek -чик. (por. магазинчик 'sklepik', трамвайчик 'tramwajek' itp.). A więc mamy w tym przypadku transidiomatyczność zakłócającą.

Transidiomatyczność możemy zauważyć także w zakresie fleksji. Wspierajacą transidiomatycznością jest podobieństwo wielu polskich i rosyjskich paradygmatów pod względem ilości i układu tworzących je form a częstokroć także pod względem wykładników konkretnych kategorii i znaczeń, por.: kurtka brata - куртка брата; autobus z turystami - автобус с туристами itp. Jako zakłócającą transidiomatyczność fleksyjną należałoby potraktować przynależność wyrazów niestanowiących problemu leksykalnego do różnych paradygmatów odmiany, np.: wybór celu - выбор цели; wnikliwa analiza - тщательный анализ itp. Tworzenie form mianownika liczby mnogiej w przypadku rzeczowników nieosobowych twardotematowych jest transidiomatyzmen wspierającym (por.: autobus - autobusy, kurtka - kurtki, jezioro - jeziora oraz автобус-автобусы, куртка-куртки, озеро - озёра), natomiast tworzenie tej samej formy w przypadku rzeczowników osobowych, rzeczowników miękkotematowych rodzaju męskiego lub żeńskiego oraz w przypadku przymiotników już należy uznać za transidiomatyczność zakłócającą, bo przyswojenie poprawnych form dla tych słów następuje powoli, zapewne pod hamującym wpływem odpowiednich form w języku rosyjskim.

Ciekawe przykłady transidiomatyczności można znaleźć w zasobach frazeologii, zarówno tej rozumianej po prostu jako łączenie wyrazów w niepredykatywne związki wyrazowe, jak i rozumianej w sposób węższy, jako zasób zwrotów idiomatycznych o różnorakim nacechowaniu ekspresywnym. Ponieważ związki frazeologiczne często mają korzenie w zjawiskach kultury, wspólnych dla wszyst- 
kich narodów europejskich, tu możemy się spodziewać częstego występowania transidiomatyczności wspierającej, i to raczej niezależnej od stopnia genetycznego pokrewieństwa języków. Przykładami wspierających transidiomatyzmów frazeologicznych polsko-rosyjskich mogą być takie, jak rząd tymczasowy - por. ros. временное правительство, koń trojański - por. ros. троянский конь, babie lato - por. ros. бабье лето i inne. Zakłócenia spowodowane transidiomatycznością w przypadku frazeologizmów mogą być różnego rodzaju, ich typy zostały pokazane wyżej przy omawianiu frezeologicznej homonimii międzyjęzykowej. Ale ponieważ tam były przykłady z pogranicza rosyjsko-czeskiego, dorzućmy tu garść przykładów z pogranicza rosyjsko-polskiego. Przykładem rozbieżności znaczenia związków wyrazowych wyglądających na ekwiwalenty thumaczeniowe są takie zwroty, jak pol. mieszkanie komunalne 'mieszkanie będące własnością jednostki samorządowej' - ros. коммунальная квартира 'wspólne mieszkanie dla dwu lub więcej rodzin'; pol. biaty kruk 'rzadki okaz, rarytas (zazwyczaj o książce)' - ros. белая ворона 'osoba zachowująca się inaczej niż całe jej otoczenie'. Są przykłady frazeologizmów, których ekwiwalencja frazeologiczna tylko częściowo znajduje odbicie w ekwiwalencji ich składników (por. pol. kość niezgody - ros. яблоко раздора). Wreszcie można znaleźć takie pary odpowiedników frazeologicznych, które mają zupełnie różny skład leksykalny, a przetłumaczone dosłownie raczej nie będą wywoływać u użytkownika języka tłumaczenia takich skojarzeń, jakie wywołuje wyjściowy frazeologizm u rodowitego użytkownika języka oryginału (por. ekspresywne oznaczanie bardzo małej ilości czegoś za pomocą polskiego frazeologizmu jak na lekarstwo; pytanie Rosjan dopiero zaczynających uczyć się polskiego o skojarzenia dosłownego rosyjskiego thumaczenia polskiego frazeologizmu pokazuje, że wyobrażenie bardzo małej ilości jakiejś substancji bynajmniej nie jest dominujące).

Zasygnalizujmy wreszcie takie zjawisko, jak transidiomatyczność składniowa. Na pewno w wielu przypadkach okazuje się czynnikiem wspierającym komunikację, bo pomiędzy językiem polskim a rosyjskim jest dużo wspólnych cech zarówno w zakresie semantyki składniowej form fleksyjnych, jak i w zakresie szyku wyrazów. Porównajmy chociażby takie zdania: pol. Przed pałacem stoi pomnik. / Pomnik stoi przed pałacem. oraz ros. Перед двориом стоит пямятник. / Памятник стоит перед двориом. Przykłady zakłócającej transidiomatyczności składniowej - to różnice rządu czasowników będących ekwiwalentami leksykalnymi (por. Nienawidze matematyki. - Ненавижу математику.), regularne znaczenia składniowe niektórych konstrukcji przypadkowych i przyimkowych (por. zdania o podobnym znaczeniu zawierające różne konstrukcje przypadkowe lub przyimkowe jako wykładniki takich samych relacji syntaktycznych: Mosty byty projektowane przez inżyniera Andrzeja Pszenickiego. - Мосты проектировались инженером Андреем Пиеницким., Przez niego spóźniliśmy się na pociag. - Из-за него мы опоздали на поезд. oraz zdania zawierające konstrukcje, 
które mogą się wydawać korelatami, ale w istocie mają zupełnie różne znaczenie: Przez dwa dni nie powiedziat ani stowa. - Через два дня мы вернёмся. 'wrócimy za dwa dni'), konstrukcje zawierające zaimek zwrotny (partykułę zwrotną) (pol.: Pedagogikę uważa się za dyscyplinę stosowana. - konstrukcja bezosobowa; ros. Педагогика считается прикладной дисциплиной. - konstrukcja bierna) i in.

Podsumowując powyższe rozważania, chciałbym podkreślić, że celem tego artykułu nie jest wprowadzenie za wszelką cenę jakiegoś novum. Analiza terminów opisujących interakcję systemów językowych w komunikacji osób niemających do dyspozycji wspólnego, w równej mierze opanowanego języka bądź w procesie przyswajania kolejnego języka pokazała, że mimo olbrzymiego dorobku praktycznego w tej dziedzinie i wytworzenia na potrzeby utrwalenia tego dorobku sporej ilości pojęć, nadal brakuje nadrzędnej nazwy dla różnych elementów systemu językowego, istotnych jako jednostki współgrające $\mathrm{z}$ elementami innego systemu językowego. Lansowana przez autora „transidiomatyczość” zdaje się spełniać wymogi w stosunku do pojęcia przydatnego na tę pozycję, ale jest na razie tylko propozycją. Być może zaakceptowanie tego pojęcia nie przyniesie większego pożytku, chyba że ułatwi formułowanie tematów badań dla potrzeb praktycznych czynności, dokonywanych na pograniczu systemów językowych. W badaniach jednak bardzo ważne jest określenie tego, co właściwie badamy, czyli wyodrębnienie przedmiotu badań za pomocą odpowiedniej nazwy. Stosując pojęcie transidiomatyczości, możemy nie tylko wyodrębnić przedmiot badań, lecz jednocześnie umiejscowić go wśród innych tematów realizowanych jako badania konfrontatywne systemów językowych pod kątem zastosowania w glottodydaktyce. Tematów takich zaś, jak pokazuje pobieżny przegląd w niniejszym artykule, jest bardzo dużo.

\section{BIBLIOGRAFIA}

Aleksandrova Z., 2010, Słowar'sinonimow russkogo jazyka. Prakticzeskij sprawocznik, Moskwa. Gębal P.E., 2016, Interkomprehensja, strategie mediacyjne i nauczanie języków obcych, w: E. Lipińska, A. Seretny (red.), Ttumaczenie dydaktyczne w nowoczesnym ksztatceniu językowym, Kraków, s. 77-93.

Hemming E., Klein H.G., Reissner Ch., 2011, English - the Bridge to the Romance Languages, Aachen.

http://www.kongrespolonistow2016.us.edu.pl/panel_8.php [08.06.2020].

Ignatyeva N., 2016, Frazeologiczeskaja meżjazykowaja omonimija kak istocznik interferencii, „Wiestnik Rossijskogo uniwersiteta drużby narodow. Russkij i inostrannyje jazyki i metodika ich priepodawanija", nr 2, s. 22-27.

Jamet M.-Ch. (ed.), 2009, Orale e intercomprensione tra lingue romanze, Venezia.

Kaleta R., 2014, Białorusko-polska homonimia międzyjęzykowa, Warszawa.

Kusal' K., 2002, Rosyjsko-polski stownik homonimów międzyjęzykowych, Wrocław.

Kusal' K., 2006, Russko-pol’skaja mieżjazykowaja omonimija kak leksikograficzeskaja problema, Sankt-Petersburg. 
Majewska M.B. (red.), 2017a, Wokót homonimii międzyjęzykowej, Warszawa

Majewska M.B., 2017b, Homonimia międzyjęzykowa - ustalenia terminologiczne, słowiański dorobek leksykograficzny, w: M.B. Majewska (red.), Wokót homonimii międzyjęzykowej, Warszawa, s. 193-216.

Pančiková M., 2005, Zradnosti pol’skej a slovenskej lexiky, Opole.

Szapkina O., 1997, Podstawowe trudności w nauczaniu języka polskiego początkujących studentów rosyjskojęzycznych, w: W.T. Miodunka (red.), Nauczanie języka polskiego jako obcego. Materiały z I Konferencji Grupy „Bristol”, Kraków.

Tezaurus terminologii translatorycznej, 1998, red. J. Lukszyn, Warszawa.

Andrey Babanov

\title{
THE TERM "TRANSIDIOMACITY" AS AN ATTEMPT TO FIND ADEQUATE LINGUISTIC NOTION FOR SOME CASES IN LANGUAGE TEACHING
}

Keywords: interlingual homonymy, interkomprehension, language teaching, Slavic languages

\begin{abstract}
The article provides a terminological proposition aimed to complement the system of notions describing interaction of language systems in various cases of communication, when the participants have significant differences in their language background, including those of language acquisition (language learning and teaching). The author proposes to use the term "transidiomacity" to mark the ability of some element of language system to provoke the uncontrolled switches of the language code due to the similarity of the element with some element in another language system. "Transidiomacity" is constructed as a generalizing notion e.g. in its relation to such notion as "interlingual homonymy", first, because it supposes not only the code switch leading to a communicative confusion (language interference), but also the one leading to better communication due to the borrowing of some means from another system (positive language transfer, intercomprehension), and, second, because it can be applied not only to the units of lexical level, but also to the units of any other level of language system (with the appropriate attributive modification of the term).
\end{abstract}

